Научная статья

УДК 81'23:81'373

DOI 10.18101/2686-7095-2021-3-72-77

\title{
ПРОБЛЕМЫ СОЗДАНИЯ СЛОВАРЕЙ РЕГИОНАЛЬНО ОКРАШЕННОЙ ЛЕКСИКИ
}

\author{
(C) Матвеева Ирина Владимировна \\ Новосибирский государственный технический университет \\ Россия, 630073, г. Новосибирск, пр. К. Маркса, 20 \\ irina.matveeva1@mail.ru
}

\begin{abstract}
Аннотация. Статья посвящена активному исследованию регионально окрашенной лексики в России и за рубежом, проблемам создания словарей регионально окрашенной лексики, популярности данного направления в разных регионах России и возможностям, которые используют авторы при создании подобных словарей. В статье анализируются и сравниваются некоторые современные словари региональной лексики, рассматриваются пласты лексики и разделы, присутствующие в этих словарях, представляется методика отбора регионально окрашенной лексики. В статье ставится вопрос о возможности создания единого онлайн-словаря региональной лексики для всех городов России, поднимается вопрос о проблемах, с которыми сталкиваются исследователи при создании словарей региональной лексики только одного города или региона, рассматриваются возможности и способы использования интернета в рамках подготовки данных словарей.

Ключевые слова: регионально окрашенная лексика, словарь региональной лексики, язык города, региональная лексикография, лексический регионализм, онлайнсловарь.
\end{abstract}

\section{Для цитирования}

Матвеева И. В. Проблемы создания словарей регионально окрашенной лексики // Вестник Бурятского государственного университета. Филология. 2021. Вып. 3. C. $72-77$.

Вопрос о региональном варьировании русского языка является одним из актуальнейших в лингвистике. Исследование регионального своеобразия русского языка осуществляется исследователями-лингвистами во многих регионах нашей страны: Т. И. Ерофеевой и Е. В. Ерофеевой в Перми [Ерофеева, 2006], [Ерофеева 2020], Т. Ю. Игнатович в Чите [Игнатович, 2009], А. П. Майоровым и В. М. Егодуровой в Улан-Удэ [Майоров, 2016], [Егодурова, 2018], Е. А. Оглезневой в Благовещенске [Оглезнева, 2013]; Е. А. Оглезневой и И. А. Парыгиной в Томске [Оглезнева, Парыгина 2018]; В. И. Теркуловым в Донецке [Донецкий региолект: монография 2018]; Р. В. Поповым в Северодвинске [Попов, 2019] и другими.

Центральное место в этих исследованиях занимает изучение региональной лексики, а именно - лексических регионализмов. Результатами работы лингвистов становится не только рассмотрение отдельных региональных слов или списков регионализмов, но и их лексикографическая интерпретация.

Составление словарей региональной лексики, словарей языка города представляет собой активные направления в лексикографии последних десятилетий. Исследователи говорят о важном и широком значении подобных словарей. По мнению Т. А. Кадоло, «работа над созданием словаря регионализмов полезна не только для 
социолингвистики и лексикографии, но и психолингвистики, так как описание неоднородности языковой нормы в области лексики делает возможным выявление ассоциативных моделей, по которым были созданы наименования и описание деятельности языкового сознания носителей региональной разновидности языка» [Кадоло, 2011, с 26].

Предполагается, что регионально окрашенная лексика не содержится в словарях нормативной лексики, что и является одним из критериев ее выделения, но на сегодняшний день это утверждение не является верным. В. И. Беликов обращает внимание филологов на то, что некоторые особенности речи, которые большинство ученых считает выходящими за пределы литературной нормы, так или иначе попадают в самые авторитетные нормативные словари, например, в (МАС) «Словарь русского языка» (под ред. А. П. Евгеньевой) или в (БТС) Большой толковый словарь русского языка (под ред. С. А. Кузнецова)» [Беликов, 2004, с. 23-24]. В качестве примеров исследователь приводит следующие лексемы: «кура» (в БТС у данной лексемы отсутствует помета «просторечное») и «водогрей» - газовая колонка (данная лексема зафиксирована в БТС, изданном в 1998 г., без помет, но, по мнению В. И. Беликова, имеет локально ограниченное употребление в Петербурге); «латка» (вид посуды) и «поребрик», которые включены в МАС без каких-либо помет, хотя, как убежден ученый, они «также имеют строгую географическую прикрепленность» [Беликов, 2004, с. 33-34]. Автор подчеркивает необходимость и в академической лексикографии учитывать региональную норму, так как «многие из такого рода единиц оказываются единственным используемым в повседневной практике (а иногда и единственно известным) способом обозначения определенного понятия для тех, кого никак нельзя исключить из числа носителей литературного языка» [Беликов, 2004, c. 27-28].

Создатели региональных словарей делают объектом лексикографического описания лексику различных пластов, изучая регионализмы как часть языка города, в который входит вся лексика, бытующая на территории изучаемой территориальной единицы. Проанализируем несколько известных словарей, чтобы выяснить общие тенденции в лексикографировании регионально окрашенной лексики.

«Словарь современного русского города» [Осипов и др., 2003] является единственным в своем роде лексикографическим изданием региональной лексики, не имеющим аналогов в России по уровню подготовки, объему работы и количеству обработанного материала. Словарь можно назвать «широким», потому что он включает в себя не только регионально ограниченную лексику, но и все слои лексики жителей Омска 1980-1990-х гг., в том числе и обсценную, то есть на примере одного города показывает всю языковую среду городского жителя тех лет. Как отмечают сами авторы, в словарь включена: 1) разговорная речь носителей литературной нормы; 2) просторечие; 3) возрастные и социальные диалекты (жаргоны); 4) бытующие в городе элементы территориальных диалектов (сельских говоров).

Рассмотрим, какие пласты лексики зафиксированы в «Словаре народноразговорной речи Архангельска» (под редакцией О. Е. Морозовой), приведем примеры из данного словаря. Название словаря говорит об очень широком охвате языка городских жителей. Итак, данный словарь включает:

1) лексику старого города; 2) реликты диалектной лексики; 3) современные городские локализмы, в том числе наименования городских реалий; 4) слова, относящиеся к общерусскому просторечию, зафиксированные в современных толковых словарях с указанием особенностей их функционирования; 5) слова, относящиеся 
к общерусскому просторечию; 6) грубо-сниженную лексику, возникшую в период социальных потрясений 1990-х гг.; 7) новую просторечно-разговорную лексику конца XX - начала XXI в., связанную с компьютеризацией, социальными сетями и новыми средствами связи; 8) разговорную и просторечную лексику, связанную с одеждой, модой, прическами, предметами быта 1996-2012 гг.

Для городских локализмов выделен один раздел, но данный словарь можно также назвать «широким», так как в данном издании на примере языка жителей Архангельска можно проанализировать речь жителя любого города в определенный период времени.

Обратимся к анализу «Регионального словаря сленга (Псков и Псковская область)» [Никитина, 2006]. Данное издание включает около 2000 регионализмов (неофициальные региональные топонимы, прозвища известных в городе людей и т. д.). Словарь содержит тематический указатель («Неформальный справочник туриста») и карту города со сленговыми наименованиями. Итак, мы можем видеть, что в данном словаре отражена одна разновидность регионализмов - неофициальные региональные топонимы.

Стоит отметить, что помимо неофициальных региональных микротопонимов в словаре содержатся также прозвища известных людей Пскова (Мямлик -бывший губернатор Псковской области, Неандерталеи - известный псковский шоумен Андрей Константинов, Металлист - житель улиць Металлистов в Пскове) и названия изделий местной промышленности (Гвозди - сушеные снетки, производимые в Пскове), которые представляют собой отдельную группу в классификации.

Анализируя общие тенденции в составлении словарей региональной лексики отметим, что особенность современных региональных словарей состоит в том, что зачастую они включают в себя не только региональные выражения, употребляющиеся в определенной местности, но и повсеместно известные за пределами региона лексемы, а именно: просторечные, жаргонные, сленговые. Вопрос о включении/невключении такого рода языковых средств остается за авторами и связан он в первую очередь с типом создаваемого словаря: должен ли он включать язык современного города, актуальный, по сути, для любого субьекта, или поставлена задача создать словарь регионально ограниченной речи (локализмов, свойственных определенному региону/части регионов).

Тем не менее ошибочно предполагать, что слова, включенные в словарь того или иного региона, употребляются только в этом регионе и нигде более. Если региональный статус слова подтверждается, то речь может идти только о том, что слово не распространено повсеместно, но вполне может быть употребимо еще в какихлибо городах. Как правило, при создании регионального словаря предполагается, что весь собранный словник в комплекте не имеет такой же частотности употребления ни в одном городе России. В качестве авторитетного мнения по этому вопросу, часто являющемуся спорным не только для обычных носителей языка, но и для лингвистов, не занимающихся регионалистикой, приведем слова В. И. Беликова руководителя проекта онлайн-словаря «Языки русских городов»: «Если слово неизвестно по соседству, это не значит, что оно не используется в том же значении гдето совсем далеко. Стержень от авторучки называется пастиком во Владивостоке и Архангельске, ксерокопию зовут отсветкой в Литве и в Амурской области. А на огромном пространстве между этими регионами так нигде не говорят... Какие-то из включенных в словарь слов и фразеологизмов известны в основном в соседних областях (как мультифора или вылдерга), другие - по всей Сибири и на Дальнем Востоке, третьи - в Сибири и на Урале (как вехотка), при этом что-то на Урале исполь- 
зуются чаще (как выпадывать/отnадывать/сnадывать). Но есть и причудливые ареалы, выявление которых довольно трудоемко» [Беликов, 2016, с. 23-24].

Рассмотрим, какие трудности стоят перед авторами словарей региональной лексики и реально ли создать объективный словарь для каждого региона России. Ответы на эти и другие вопросы в некоторой степени можно получить, обратившись к опыту разработки онлайн-словаря «Языки русских городов».

Онлайн-словарь «Языки русских городов» создавался с 2005 г. усилиями коллектива социолингвистов и обычных граждан под руководством В. И. Беликова. Каждое слово, включенное в данный словарь, является региональным для того или иного города/области/региона. Чтобы слово попало на электронную страницу этого издания, оно должно быть не общеупотребительным, а характерным только для определенной/определенных области/областей и/или региона. Каждое слово, предлагаемое для обсуждения, мог прокомментировать на форуме любой участник. Иначе говоря, прежде чем слово попадет в словарь, авторы-разработчики должны собрать о нем как можно больше сведений-комментариев, позволяющих проверить его распространенность в том или ином регионе с помощью программ-поисковиков и энтузиастов, помогающих узнать, используется ли слово в местных СМИ, блогах и т. д. В настоящее время работа над словарем приостановлена, но формат работы по созданию словаря представляется актуальным и наиболее эффективным даже для печатных изданий.

Интернет-технологии и их возможности вносят большой вклад в проведение исследований в лингвистике и, в частности, в регионалистике, в первую очередь благодаря точному и быстрому анализу информации.

Один из инструментов проверки слов на региональную ограниченность с помощью поисковой системы Яндекс был впервые описан и применен В. И. Беликовым и М. В. Ахметовой. Инструмент состоит в том, что, введя любой поисковый запрос (лексему) в строчку поиска Яндекс или в дополнительный сервис Яндекс.Wordstat, возможно отследить частотность данного запроса по регионам поиска (см. [Ахметова, 2014], [Беликов, Ахметова, 2009]).

«Интернет как средство коммуникации носителей разных региолектов видится благоприятной средой для выявления региональных лексических особенностей, особенно если учитывать явление «неосознанного регионализма» (когда использующий в повседневной речи ту или иную лексему человек не осознает, что это слово может быть неизвестно в другом регионе)» [Беликов, 2016]. Как нам представляется, надежной методикой отбора может являться следующая поэтапная процедура, которая предполагает активное использование интернета: 1) сбор предполагаемых регионально ограниченных слов (из различных источников); 2) опрос иногородних жителей (онлайн-анкетирование); 3) опрос жителей города, лексика которого изучается; 4) работа с базами данных (поиск подтверждающих контекстов); 5) работа со словарями (толковые словари, словари разговорной речи); 6) работа с сервисом Яндекс.Wordstat.

Несмотря на то, что составители онлайн-словаря «Языки русских городов» проводили своего рода масштабный социолингвистический эксперимент, который велся на протяжении более десяти лет и позволял избежать проблем, встречающихся при создании печатных словарей одного региона (нерепрезентативное общее число информантов, недостаточное количество подтверждений, отсутствие мнений жителей других регионов и т. д.), появляются вопросы об общеупотребительности слов, име- 
ющих отношение к жаргонной лексике. Такие слова (тем более если это региональные жаргонизмы) могут быть неизвестны среднестатистическим жителям региона.

Масштаб работы, проводимой по созданию онлайн-словаря, говорит о том, что для качественного отбора материала требуется достаточное количество как исследователей, так и усилий со стороны авторов и разработчиков: проверка, модерирование, применение онлайн-технологий и т. д. Онлайн-коммуникации постоянно набирают обороты, и такое объединение ученых и других заинтересованных граждан из разных городов представляется необходимым и наиболее продуктивным для создания словарей регионализмов.

\section{Литература}

1. Ахметова М. В. Лексические регионализмы и локализмы в русскоязычном Интернете // Русский язык и новые технологии / составитель Г. Ч. Гусейнов ; под редакцией М. В. Ахметовой, В. И. Беликова. Москва: Новое литературное обозрение, 2014. С. 155-171. Текст: непосредственный.

2. Беликов В. И. Yandex как лексикографический инструмент // Компьютерная лингвистика и интеллектуальные технологии: труды международной конференции. Диалог'2004. Москва: Наука, 2004. С. 39-46. Текст: непосредственный.

3. Беликов В. И. О словарях региональной лексики : вступительное слово // Словарь региональной лексики и народных топонимов города Новосибирска. 2-е стер. изд. Новосибирск: Свиньин и сыновья, 2016. С. 16-26. Текст: непосредственный.

4. Беликов В. И. Сравнение Петербурга с Москвой и другие соображения по социальной лексикографии // Русский язык сегодня. Вып. 3. Проблемы русской лексикографии. Москва: Изд-во Ин-та русского языка РАН, 2004. С. 23-38. Текст: непосредственный.

5. Донецкий региолект: монография / В. И. Теркулов, Н. П. Курмакаева, В. И. Мозговой [и др.]; под редакцией В. И. Теркулова. Донецк: Фолиант, 2018. 265 с. Текст: непосредственный.

6. Егодурова В. М. Русский язык в Байкальском регионе: лексико-семантический аспект: монография. Удан-Удэ: Изд-во Бурят. гос. ун-та, 2018. 124 с. Текст: непосредственный.

7. Ерофеева Е. В. Локализмы в литературной речи горожан: методический аспект, теоретические проблемы // Актуальные проблемы русской диалектологии / ответственный редактор Л. Л. Касаткин. Москва, 2006. С. 57-58. Текст: непосредственный.

8. Игнатович Т. Ю. К вопросу о региональной языковой специфике в отражении русской ценностной картины мира // Новое в славянской филологии: сборник статей / ответственный редактор М. В. Пименова. Севастополь: Рибэст, 2009. Сер. Славянский мир. Вып. 4. С. 222-228. Текст: непосредственный.

9. Кадоло Т. А. Региональная лексика как проявление поликультурности // Язык и культура. 2011. № 2 (14). С. 22-28. Текст: непосредственный.

10. Майоров А. П. Региолект и регионализмы в современной языковой ситуации России // Известия РАН. Серия литературы и языка. 2016. Т. 75, № 1. С. 51-55.

11. Никитина Т. Г., Рогалева Е. И. Региональный словарь сленга (Псков и Псковская область). Москва: ЭЛПИС, 2006. 382 с. Текст: непосредственный.

12. Оглезнева Е. А. Дальневосточный региолект русского национального языка: к вопросу о его формировании и специфике // Региональные варианты национального языка: материалы всероссийской (с международным участием) научной конференции / научный редактор А. П. Майоров. УланУдэ: Изд-во Бурят. гос. ун-та, 2013. С. 81-83. Текст: непосредственный.

13. Оглезнева Е. А., Парыгина И. А. О региональной окрашенности лексики (по данным анкетирования носителей русского литературного языка в г. Томске) // Вестник 
Воронежского государственного университета. Сер. Лингвистика и межкультурная коммуникация. 2018. № 4. С. 127-132. Текст: непосредственный.

14. Попов Р. В. Как это будет по-северодвински?: словарь местной лексики Северодвинска: [18+] / Северный (Арктический) федеральный университет имени М. В. Ломоносова. Архангельск: Изд-во САФУ, 2019. 287 с. Текст: непосредственный.

15. Словарь народно-разговорной речи города Архангельска: в 3 томах / составитель Е. Е. Котцова [и др.]; под общей редакцией О. Е. Морозовой; Северный (Арктический) федеральный университет имени М. В. Ломоносова. Т. 1. Городское просторечие. Архангельск: Изд-во САФУ, 2013. 204 с. Текст: непосредственный.

16. Словарь современного русского города (на материале города Омска) / под редакцией Б. И. Осипова. Москва: Русские словари, 2003. 566 с. Текст: непосредственный.

17. Ерофеева Т. И. Социолингвистический глоссарий пермских локализмов: 60-90-е годы XX века: словарь / Пермский государственный национальный исследовательский университет. Пермь: Изд-во ПГНИУ, 2020. 239 с. Текст: непосредственный.

Статья поступила в редакцию 19.09.2021; одобрена после рецензирования 15.10.2021; принята к публикации 29.10.2021.

\section{PROBLEMS OF CREATING DICTIONARIES OF REGIONAL LEXIS}

\section{Irina V. Matveeva}

Novosibirsk State Technical University

20 K. Marksa Prospect, Novosibirsk 630073, Russia

irina.matveeva1@mail.ru

Abstract. The article deals with the problems of creating dictionaries of regional lexis in Russia and abroad, the relevance of this direction in different Russian regions and the methods that the authors use when they are creating such dictionaries. We have analyzed and compared some modern dictionaries of regional lexis, considered the layers of vocabulary and the sections that they presents in these dictionaries, as well as the methodology for selecting regional lexis. The article raises the question of the possibility of making a single online dictionary of regional lexis for all Russian regions, analyzes the problems faced by researchers when they are creating dictionaries of regional lexis of one city or region, discusses the possibilities and ways of using the Internet in creation of such dictionaries.

Keywords: regional lexis, dictionary of regional lexis, language of a city, regional lexicography, lexical regionalism, online dictionary.

\section{For citation}

Matveeva I. V. Problems of Creating Dictionaries of Regional Lexis. Bulletin of Buryat State University. Philology. 2021; 3: 72-77 (In Russ.).

The article was submitted 19.09.2021; approved after reviewing 15.10.2021; accepted for publication 29.10.2021. 